\title{
Onar Aanestad
}

\section{Klarspråksledelse - mer enn gode tekster}

Fra 2009 til 2012 gjennomførte Statens pensjonskasse (SPK) en stor satsing på klarspråk. Vi forbedret mer enn 300 brev, forenklet alt innhold på nett og laget informasjon om pensjonsreformen i klarspråk. Arbeidet ble belønnet med Klarspråksprisen 2011.

Prosessen var langt fra knirkefri. For SPK ble klarspråksledelse nøkkelen for å lykkes med klarspråk. Denne artikkelen prøver å forklare hva vi loerte.

\section{Mer enn brukertilpasset språk}

Mens Språkrådet definerer klarspråk som «... korrekt, klart og brukertilpasset språk i tekster fra det offentlige», forsto SPK fort at klarspråk måtte handle om mer enn å lage gode tekster. Da administrerende direktør i SPK, Finn Melbø, mottok klarspråksprisen, poengterte han: «Det ligger i samfunnsansvaret vårt å sørge for at informasjonen når frem til alle den angår.» SPK måtte prøve å gjøre klarspråk til et verktøy for å nå strategiske mål - og å løse samfunnsoppdraget. For å få til det måtte vi bruke ressurser på å planlegge, organisere og lede klarspråkssatsingen. Klarspråksledelse - med en aktiv prosjekteier i toppledelsen og en dedikert prosjektleder - gjorde at klarspråk gikk fra å være en ad hoc-satsing til et prioritert tiltak som endret måten vi tenkte og jobbet på.

\section{Måtte vise strategisk verdi}

Selv om de fleste lederne var positive da klarspråk kom på agendaen i 2009, var konkurransen om oppmerksomheten og ressursene hard. SPK, som alle andre virksomheter, hadde mange oppgaver som det hastet å løse. Mange viktige oppgaver måtte 
nedprioriteres og utsettes fordi vi ikke hadde nok penger eller ressurser, og fordi andre oppgaver ble vurdert som mer kritiske.

Forankring ble avgjørende. Administrerende direktør gikk foran og erklærte seg som klarspråksgeneral. Støtte fra Difi gjorde at vi kunne starte et pilotprosjekt raskt for å høste erfaringer og vise de første resultatene. Likevel var de fleste lederne villige til å ofre klarspråk når det ble kniving om ressursene. Forankringen var altså sterk på toppen og svakere nedover.

Samtidig forsto vi at antallet brev som skulle forbedres, var så stort at vi ville trenge cirka to årsverk og flere millioner kroner til teknisk implementering $i$ ett til to år for å kunne løse oppgaven. Klarspråk måtte kjempe en intern kamp om ressursene. For å vinne frem måtte vi vise at klarspråk ikke bare var en ekstrasatsing, men et verktøy for å nå strategiske mål som ledelsen var opptatt av. Vi tok utgangspunkt i noen grunnleggende spørsmål: Hvordan kunne bedre innhold på nettstedet bidra til økt selvbetjening, færre henvendelse og reduserte kostnader? Hvordan kunne vi gjøre arbeidet med å endre brev mer effektivt? Og hvordan skulle vi sikre høy kundetilfredshet?

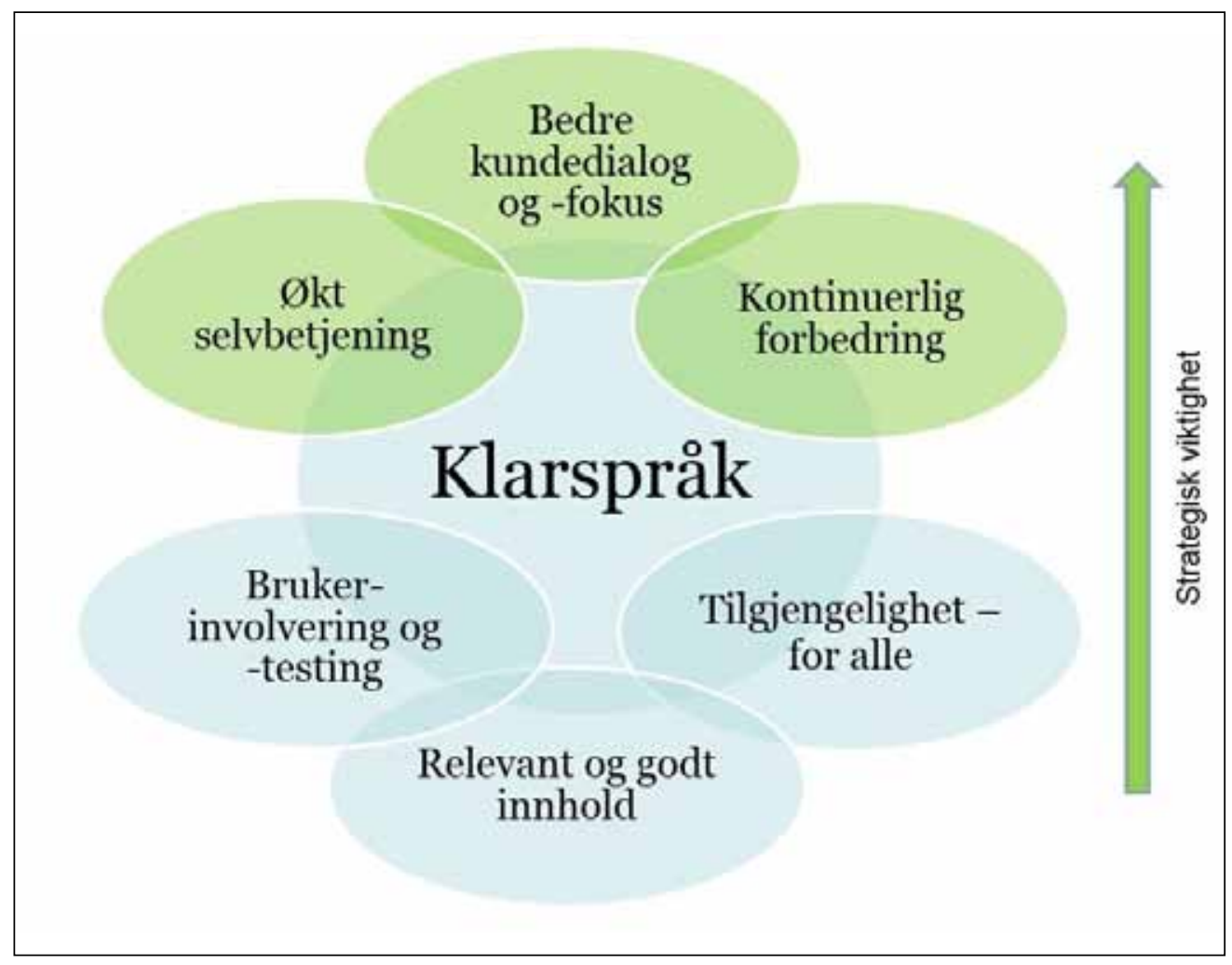

Figur 1: ledelsens språk vs. klarspråk 


\section{Vi måtte snakke ledelsens språk}

Selv om lederne var positive til begreper som økt tilgjengelighet, bedre innhold og brukerinvolvering, var disse målene i praksis ikke viktige nok når kampen om ressursene var hard. Det var lettere å få gjennomslag når vi klarte å vise hvordan klarspråk var koplet til mål og begreper som ledelsen la stor strategisk vekt på.

\section{Pensjonsreformen åpnet dorene}

Pensjonsreformen og SPKs IT- og endringsprosjekt Perform viste seg å være en døråpner for klarspråk. Perform - som er en kortform for Pensjon for fremtiden - handlet om langt mer enn pensjonsreformen. Fire oppgaver falt sammen i tid og ble slătt sammen til samleprosjektet Perform:

1. Vi måtte bygge ny løsning for overføring av data mellom SPK og Navs pensjonsprogram. Denne oppgaven var en følge av Nav-reformen. Løsningen måtte være klar innen 1.1.2009. Derfor måtte SPK bygge løsningen i 2008.

2. Vi måtte forberede håndteringen av nytt regelverk for arbeidsavklaringspenger (AAP). Løsningen måtte være klar til mars 2010.

3. Vi måtte legge til rette for nytt regelverk i pensjonsreformen. Opprinnelig frist var 1.1.2010, men fristen ble utvidet av Stortinget til 1.1.2011.

4. Vi måtte bygge nytt saksbehandlingssystem på en ny teknologisk plattform innen 1.1.2011 for at SPK skulle klare å levere de tre første oppgavene.

Prosjektet startet i 2008 og ble avsluttet i mars 2012. Perform hadde en egen prosjektorganisasjon med 175 personer. 100 eksterne konsulenter fra tre leverandører og 75 SPK-ansatte jobbet i prosjektet på hel- eller deltid. Litt enkelt sagt skulle SPK etablere en middels stor bedrift, modernisere den teknologiske plattformen, investere én milliard kroner i en ny og fremtidsrettet teknologisk plattform, innføre pensjonsreformen, avvikle den mellomstore bedriften - og være tilbake i vanlig drift i løpet av fire år.

\section{Motte informasjonsbehovet med klarspråk}

Vi forsto tidlig at det ville oppstå et stort informasjonsbehov blant mange av våre medlemmer og deres arbeidsgivere om hva pensjonsreformen ville bety for dem. 8 av 10 medlemmer i SPK oppga at de ønsket mer informasjon om hva pensjonsreformen ville innebære for dem. Dersom de seks årskullene som kunne bli pensjonister i 2011 ikke forsto konsekvensene av de nye reglene, risikerte de å ta valg på feil premisser og tape penger, eller velge en løsning som ikke var den beste for dem. Vi forventet også at usikkerheten ville føre til en massiv økning i antall henvendelser. I tillegg ville henvendelsene bli mer kompliserte enn før, fordi de ville kreve beregning av personlig pensjon etter regler som fortsatt ikke var klare. 
Ett av tiltakene SPK prioriterte, var å opprette en tverrfaglig intern arbeidsgruppe - Task Force Inform. Gruppen skulle forklare endringene på en lettfattelig måte, altså i klarspråk. Gruppen skulle blant annet gi kundesenteret det som var nødvendig for å kunne svare på henvendelser.

\section{Unngikk massiv oppbemanning}

De tidlige analysene viste at kundesenteret alene måtte oppbemanne med 20 personer, fra 16,8 stillinger i 2007 til 36,6 stillinger i 2011, med mindre vi klarte å gi gode og riktige svar gjennom andre kanaler som spk.no, brev eller samarbeid med andre pensjonsaktører som Nav. Det tilsvarer ca. 12 millioner kroner i lønnskostnader.

Fasiten ble slik: Antallet henvendelser til kundesenteret ble nesten fordoblet fra 2009 til 2011, mens antallet ansatte kun økte fra 21 i 2009 til 27 i 2011, som var 9,6 færre enn forventet i 2007. Samtidig økte antallet henvendelser som ble besvart per årsverk, fra 7571 i 2009 til 8182 i 2011 - en indikasjon på at kundesenteret og betjeningen hadde blitt mer effektive. Selv om klarspråk bidro, var kloke grep og god ledelse av kundesenteret trolig den viktigste grunnen til det gode resultatet.

\section{Perform - en mulighet og en utfordring for klarspråk}

Perform var som et tog i høy hastighet som alle ansatte måtte forholde seg til på ulike måter. Det gjaldt også klarspråksprosjektet. På den ene siden var Perform en mulighet til å skaffe penger og ressurser til å gjøre et klarspråksløft. På den andre siden var Perform en utfordring, fordi det skjedde så mye så fort.

For eksempel forsto vi litt sent at brevprosjektet måtte koples tett på Performs arbeid med å bytte ut den eksisterende brevløsningen med en mer moderne løsning. Selv om vi fikk penger gjennom Perform til å legge inn nye brev i det nye brevsystemet, gjorde mangelfull koordinering og oversikt at prosessen ikke ble tilfredsstillende. I ettertid så vi at overgangen fra gammel til ny brevløsning burde vært planlagt bedre. Vi fikk ikke gjennom så mange endringer som vi hadde ønsket, på grunn av knapphet på tid og ressurser. Med bedre koordinering kunne vi trolig ha forbedret flere brev tidligere, slik at de lå klare til å legges inn i den nye brevløsningen. For en del brev var det ikke tilstrekkelig tid til å gjøre forbedringene vi mente var nødvendige. Erfaringen viste nok en gang hvor viktig det var å kople klarspråk på eksisterende prosesser, tiltak og satsinger.

\section{Klarspråk handler mye om IT}

Et eksempel på at klarspråk handler om mer enn gode tekster, er kostnadene SPK hadde for å kunne ta forbedrede brev i bruk. Ett såkalt helmaskinelt brev, som skulle hente persondata fra mange ulike systemer og gå ut automatisk til titusenvis av medlemmer, kostet ca. 60000 kroner å implementere i de tekniske systemene. Denne lær- 
dommen tok det tid å få. Da vi forbedret 20 av våre viktigste brev i pilotprosjektet $\mathrm{i}$ 2008, viste brukertester at brevene hadde blitt langt bedre. Men senere viste det seg at brevene aldri hadde blitt lagt inn teknisk i saksbehandlingssystemet. Brukerne mottok fortsatt - til vår overraskelse - de gamle brevene som var vanskelige å forstå. Etter denne aha-opplevelsen endret vi arbeidsrutinen for forbedring av brev, slik at IT og teknisk implementering ble lagt til som siste stasjon i prosessen. Vi lærte at det kunne, og i mange tilfeller måtte, ta flere måneder fra arbeidet med å forbedre et brev startet til det var klart til å brukes. For mange var dette frustrerende og vanskelig å akseptere, men den nye kunnskapen gjorde det lettere å styre forventninger.

\section{Fire tiltak for å gjore noe vanskelig mulig å forstå}

I tillegg til den tverrfaglige arbeidsgruppen som hadde ansvar for å informere om endringer som følge av pensjonsreformen, prioriterte SPK fire tiltak hvor vi kunne kople på klarspråk:

\section{SPK lanserte nytt nettsted samtidig med at pensjonsreformen trådte i kraft.}

Analysen viste at det gamle nettstedet var stort, og at mange temaer burde skrives om. Timingen var god. Pensjonsreformen innebar at vi måtte gjennomgå og endre store deler av informasjonen om pensjon på grunn av regelendringene. Løsningen ble å forkaste alt innhold og bygge opp nettstedet på nytt, basert på analyser av hva brukerne faktisk etterspurte. Dermed slapp vi å ta med oss dårlige formuleringer. Det ble enklere å skrive slik vi mente var riktig. Antall sider ble halvert, som igjen betydde at jobben med å forvalte og holde innholdet oppdatert ble halvert, og at risikoen for utdatert og ikke korrekt innhold ble vesentlig redusert. Redaksjonsgruppen skrev alt innhold på nytt i tråd med nye skriftlige retningslinjer og en streng innholdsstrategi. Språket ble klarere og enklere. Sammen med ny informasjonsarkitektur og design på nettstedet førte disse grepene til at antall sider brukeren trengte å besøke før han eller hun fikk hjelp, også ble halvert. Altså: tid og penger spart for SPK, tid og frustrasjon spart for brukeren.

\section{SPK forbedret mer enn $\mathbf{3 0 0}$ av totalt $\mathbf{5 0 0}$ brev i et omfattende brevprosjekt.}

Selv om dette utgjorde 60 prosent av det totale antallet brev, forbedret vi de viktigste brevene som gikk til mange - noen ganger titusenvis - av medlemmene våre. De fleste brevene som gjensto, vurderte vi som mindre sentrale og viktige. Brev som var vanskelige å forstå, førte til to hovedutfordringer: mange henvendelser på telefon - eller at mottakerne lot være å svare på ting som kunne føre til at de gikk glipp av det de hadde krav på. De fleste personene som arbeidet med å forbedre innholdet i brevene, var også med i redaksjonsgruppen for SPKs nettsted spk.no. Det gjorde det enklere å gjenbruke formuleringer og å sikre lik informasjon både på nett og $\mathrm{i}$ brev. 
En viktig oppgave i arbeidet med å endre brev var å vurdere brevets «forretningsmessige verdi» for SPK, eller om det kunne erstattes med informasjon på nett, slås sammen med ett eller flere andre brev eller rett og slett slettes. En slik opprenskning gjorde at vi fikk færre brev å forvalte også teknisk og at vi reduserte risikoen for at saksbehandlere kunne bruke ulike - og potensielt utdaterte - brevmaler.

Brevprosjektet disponerte cirka 2,4 årsverk i tre år. En stilling var dedikert prosjektleder, som hadde ansvar for å ha oversikt over status på alle brev og lede det operative, tverrfaglige forbedringsarbeidet. 1,1 stilling var dedikert fagpersoner, mens juridisk og IT bidro med en person hver i henholdsvis 10- og 20-prosents stilling.

Vår erfaring var at et mindre team med få, faste personer jobbet mer effektivt enn når flere personer fra de samme fagmiljøene deltok. Årsaken var at teamet gjennom konkrete diskusjoner fant felles løsninger og kjøreregler. Det var vanskeligere når flere personer og meninger var involvert i starten. Derfor etablerte vi ett fast, tverrfaglig brevteam. Ulempen var at kompetansen og forståelsen for klarspråk, arbeidsprosess og den formelle rutinen for forbedring av brev ble samlet på få personer. Det økte sårbarheten da vi gikk fra prosjekt til ordinær drift.

\section{Rutine for endring av brev}

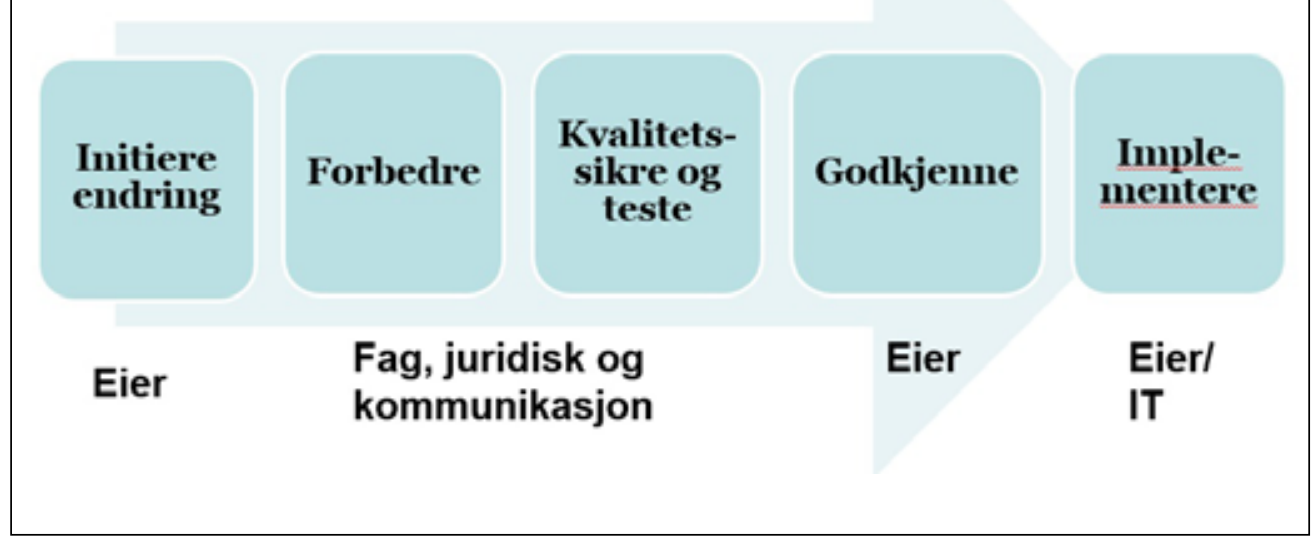

Figur 2: rutine for endring av brev i Statens pensjonskasse 


\section{SPK utarbeidet en pensjonskalkulator hvor medlemmene kunne legge inn enkle data om seg selv.}

Brukertester viste at vi først måtte forklare hvilke alternativer den enkelte kunne velge mellom: å bli pensjonist på heltid, å jobbe deltid eller å ta ut full pensjon og jobbe heltid ved siden av. Deretter ønsket brukeren å se hva ulike valg innebar for å vurdere hva som lønnet seg, og hvordan ulike kombinasjoner slo ut. Det var altså ikke nok å skrive enkelt. Vi måtte i tillegg være tydelige på valgalternativ og konsekvenser - med visuelle virkemidler som støtte.

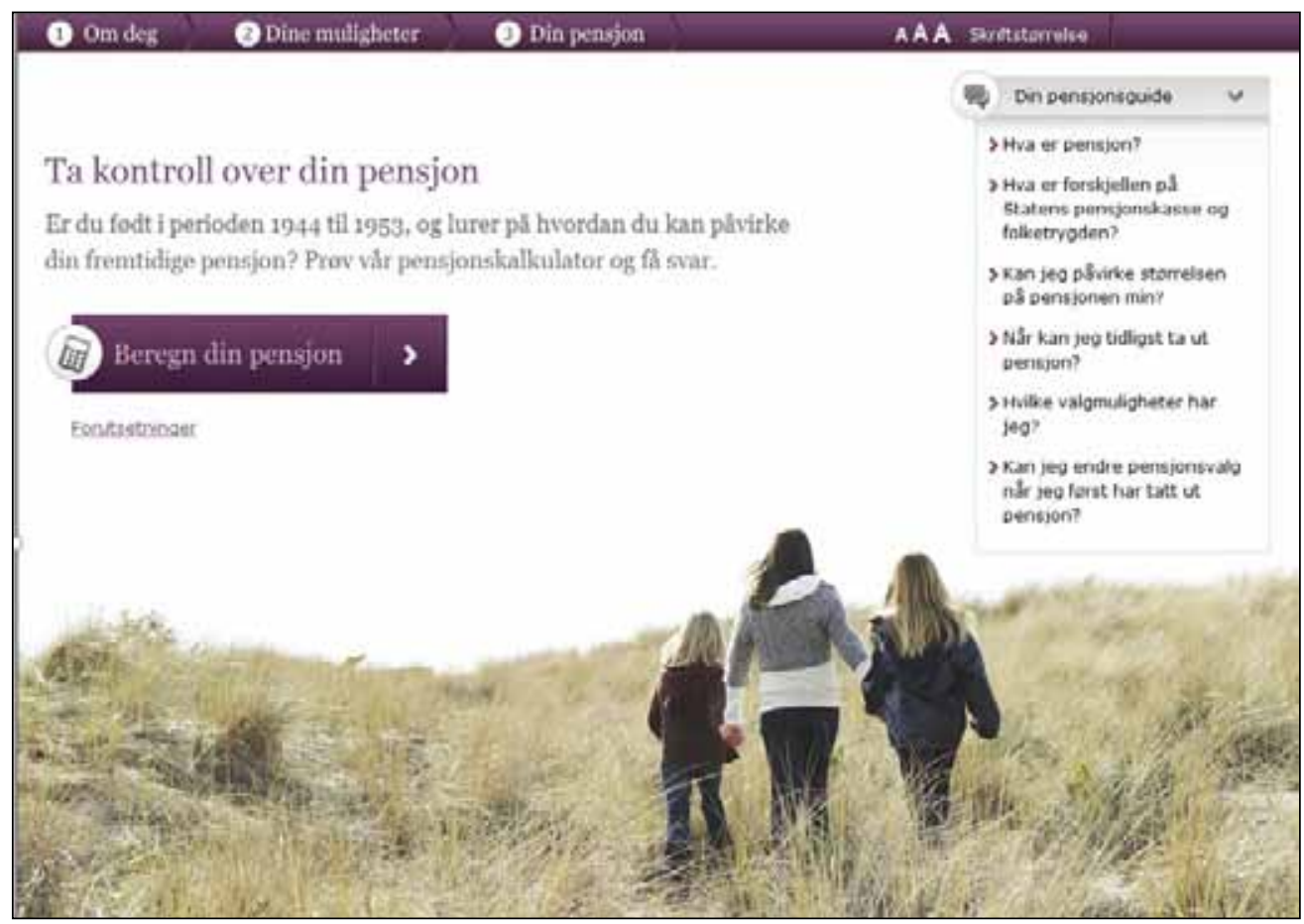

Pensjonskalkulator 1 


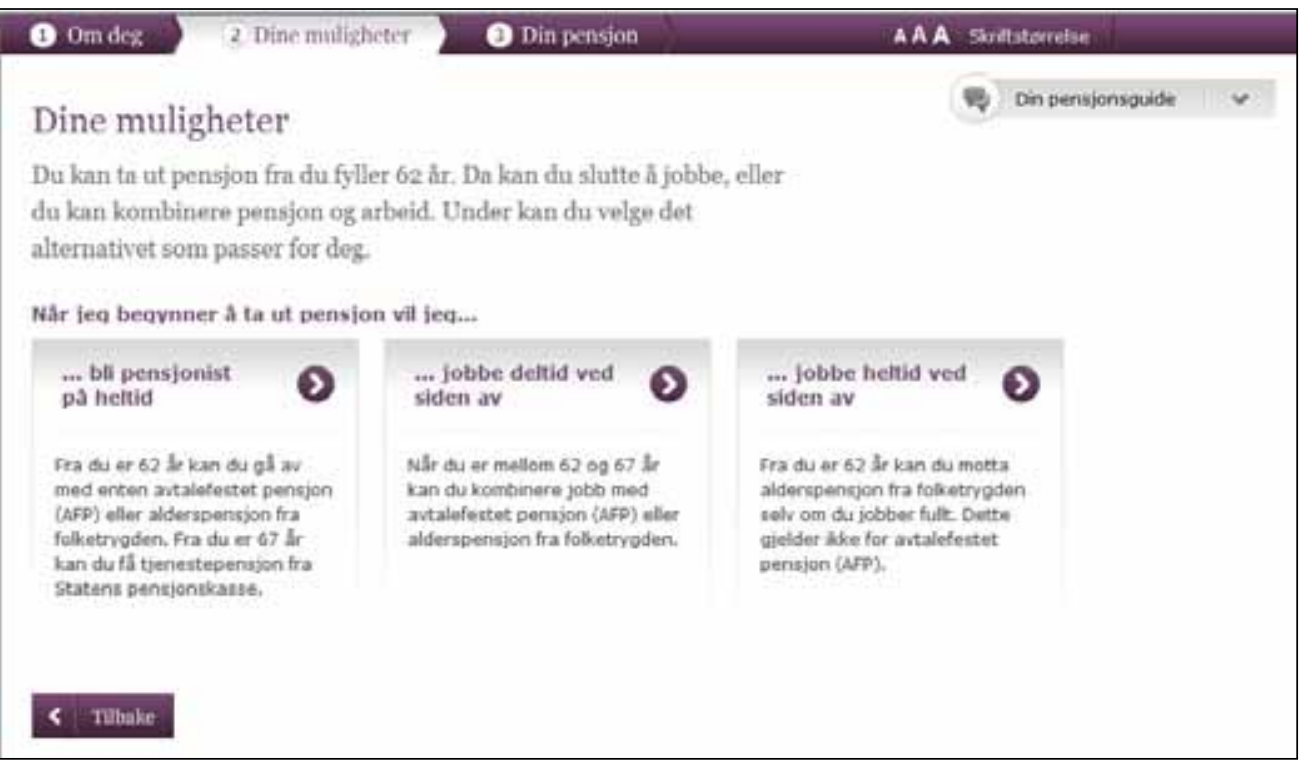

\section{Pensjonskalkulator 2}

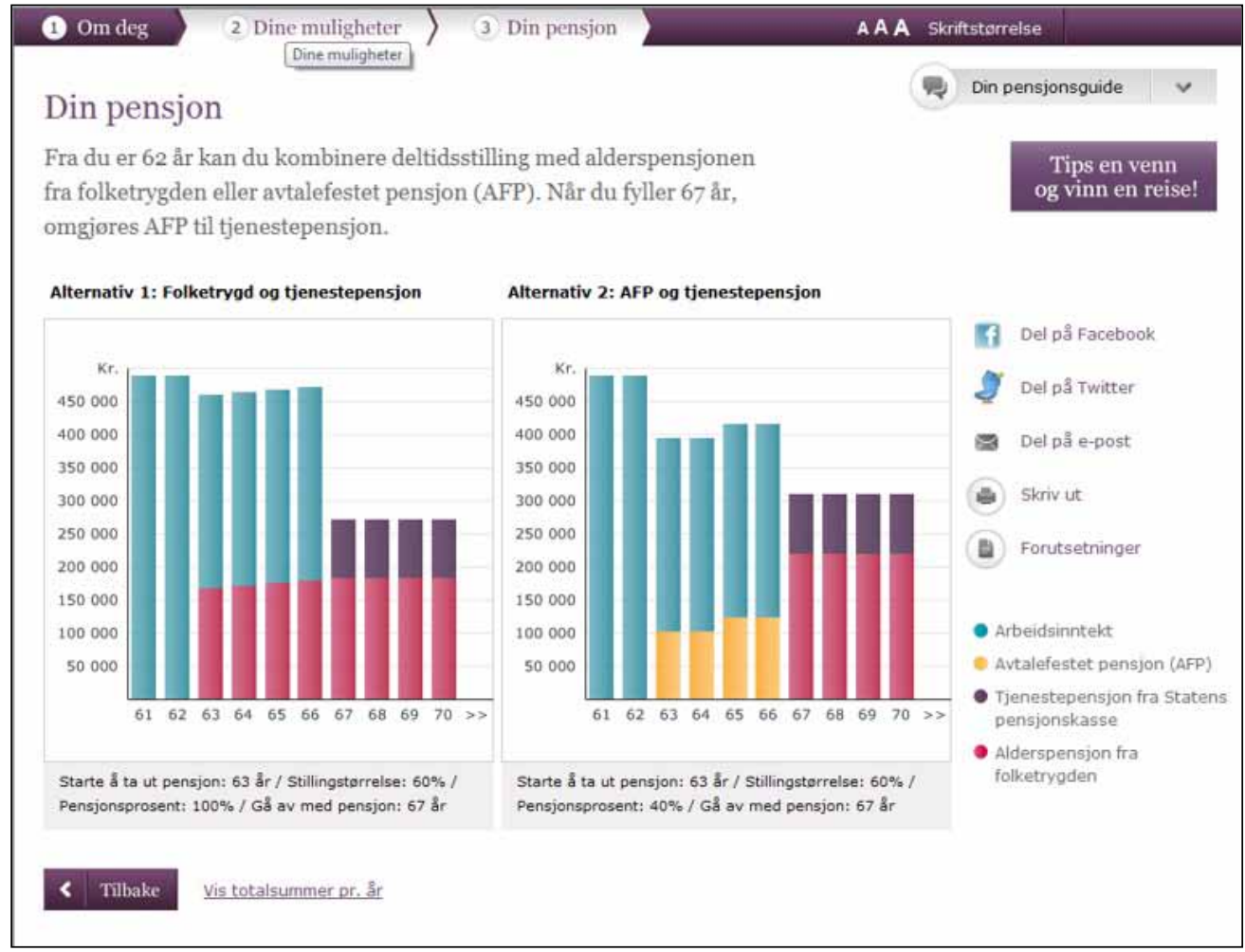

\section{Pensjonskalkulator 3}

14 Fra myndig maktspråk til klar kommunikasjon 


\section{SPK informerte om pensjonsreformen på tegnspråk.}

Offentlige reformer får konsekvenser for enkeltpersoner. Tegnspråklige nordmenn, spesielt eldre, har norsk skriftspråk som andrespråk. Tegnspråk skiller seg vesentlig fra norsk skriftspråk. SPK forsto at pensjonsreformen var vanskelig å forstå i utgangspunktet. Dialog med døve personer lærte oss at vi burde formidle det viktigste ved pensjonsreformen også på tegnspråk. Derfor laget vi Norges første tegnspråklige nettsted i samarbeid med Signo Rycon, som både har kompetanse på tegnspråk og produksjon av video. Senere deltok vi i et samarbeid med andre pensjonsleverandører hvor vi laget ytterligere syv filmer om pensjonsreformen - med og uten tegnspråk. Tilbakemeldinger fra døve nordmenn viste at dette var nyttig og viktig for dem. Men også andre brukergrupper fikk nytte av arbeidet. For å kunne oversette informasjonen fra norsk tekst til norsk tegnspråk måtte vi forenkle og bruke klarspråk. Samarbeidet med oversetterne presset oss til å forenkle ytterligere. Resultatet ble enklere og klarere informasjon om pensjonsreformen, til glede og nytte for alle. Vi lærte også at det verken var spesielt kostbart eller vanskelig å lage informasjon på tegnspråk. Det krevde kun av vi jobbet litt annerledes og hadde en god samarbeidspartner på tegnspråk.

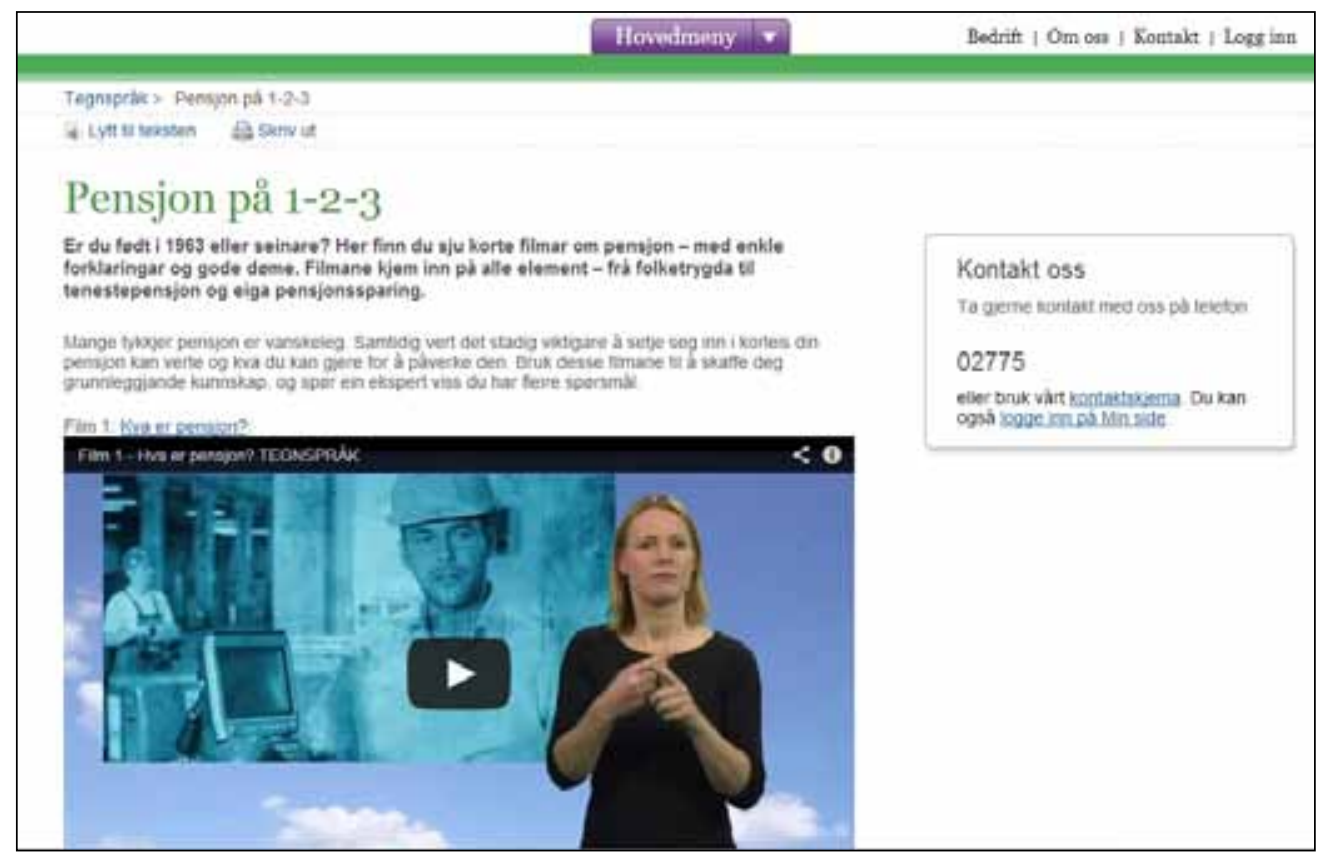

Figur 3: pensjonsreformen på tegnspråk 


\section{Dette lærte vi}

\section{Lærdom 1: Klarspråk måtte handle om mer enn å lage gode tekster}

Språkrådet definerer klarspråk som «... korrekt, klart og brukertilpasset språk i tekster fra det offentlige». Administrerende direktør i SPK var mer opptatt av at klarspråk var en del av samfunnsoppdraget. Vi måtte sørge for at informasjonen nådde frem til alle den angikk. Klarspråk måtte handle om mer enn å lage gode tekster.

\section{Lærdom 2: Vi måtte bruke ledernes språk}

Da klarspråk kom på agendaen for fullt i 2009, var de fleste lederne positive. Men kampen om ressursene internt var hard. For å vinne frem måtte vi vise at klarspråk ikke bare var en ekstrasatsing, men et verktøy for å nå prioriterte mål som ledelsen var opptatt av. Vi tok utgangspunkt i noen grunnleggende spørsmål: Hvordan kunne bedre innhold på nettstedet bidra til økt selvbetjening og reduserte kostnader? Og hvordan kunne vi lykkes bedre i dialogen med medlemmene og kundene, slik at vi kunne nå målene vi hadde satt for kundetilfredshet og færre henvendelser? Med andre ord: Vi måtte forstå og bruke ledernes språk for å gjøre klarspråk relevant og viktig nok.

\section{Lærdom 3: Vi måtte jobbe medstrøms}

Det viktigste for ledere og ansatte i perioden klarspråksprosjektet varte, var å gjennomføre den krevende pensjonsreformen og et stort IT- og endringsprosjekt. Strategisk mål nummer én var å effektivisere arbeidet. Klarspråk fikk ganske gode vilkår når vi klarte å kople oss på tiltak og satsinger som allerede var definert som viktige. Vi måtte bruke mulighetene der og når de oppsto, enten det var da nettstedet med alt innhold skulle lages på nytt, da vi måtte endre brev på grunn av nye regler i pensjonsreformen, eller da alle brev uansett måtte flyttes fra gammel til ny teknisk brevløsning.

\section{Lærdom 4: Vi måtte skape nødvendige rammebetingelser}

Ledelse var avgjørende for å få rom til gjøre jobben. Vi forsto raskt at klarspråk ikke bare handlet om å forbedre enkelttekster, men om å skaffe ressurser, endre rutiner og endre måten organisasjonen løste oppgaver på. Det var også nødvendig med en prosjektleder som kunne skaffe oversikt over status på ulike områder, slik at ledelsen fikk nødvendig informasjon til å prioritere riktig.

\section{Lærdom 5: Klarspråk er en tverrfaglig øvelse}

Klarspråk krever at nesten alle fagmiljøer må involveres, for eksempel når et brev skal forbedres og tas i bruk. Hvem skal betale, hvem skal gjøre hva, hvem bestemmer mest om vi er uenige - juristen, saksbehandleren eller kommunikasjonsrådgiveren - og hvilke brev er viktigst? Det er eksempler på spørsmål vi måtte håndtere jevnlig. Faggrupper og avdelinger var ofte uenige i vurderinger og prioriteringer. Det er naturlig. 
Da måtte prosjekteier, i kraft av sin rolle som toppleder, finne løsninger sammen med andre ledere. Det hadde vært vanskeligere for prosjektlederen, som hadde en rådgiverstilling.

\section{Lærdom 6: Overgangen fra prosjekt til vanlig drift var tøff}

Alle prosjekter skal ta slutt. Da SPK bestemte seg for å avslutte klarspråksprosjektet etter tre år uten å videreføre en sentral koordinator, ble ansvaret spredd på flere. Det ble vanskelig å holde oversikt og å prioritere tiltak i ulike enheter opp mot hverandre. Klarspråksarbeidet ble mindre oversiktlig, og - litt satt på spissen - alle ble automatisk mer opptatt av sine egne mål enn virksomhetenes. Oversiktene og statusbeskrivelsene smuldret hen. Å fjerne den koordinerende rollen hadde sin pris.

\section{Lærdom 7: Klarspråk bidro til bedre rapportering og styringsdialog}

Direktoratet for økonomistyring (DFØ) publiserte nettopp en analyse som viser at rapporteringen til statlige virksomheter er utydelig og for lite konkret. SPK har jobbet hardt for å forbedre rapporteringen helt fra 2008. Klarspråk var naturlig del av SPKs kommunikasjon, også i arbeidet med årsrapporten. Klarspråk viste seg som et verdifullt verktøy til å kommunisere mål, resultater og avvik tydeligere - både internt og mot departementet.

\section{Lærdom 8: Vi manglet en plan for gevinstrealisering}

Selv om vi kunne vise til gode enkeltresultater, for eksempel ved store brevutsendelser, var vi ikke flinke nok til å definere mål, inkludert hvilke gevinster vi skulle oppnå. En plan for gevinstrealisering ville gitt klarspråk større tyngde, relevans og gjennomslagskraft og vist hvordan klarspråk ville bidra til å nå mål som topp- og mellomledere var opptatt av og ble målt på.

\section{Lærdom 9: Effekter må planlegges og måles}

Som de fleste andre virksomheter som har jobbet mye med klarspråk, forsto vi i etterkant at vi burde hatt en klarere plan og metode for hvordan vi skulle måle og dokumentere resultater og effekter fra start til mål. Harde tall og fakta ville gitt klarspråksarbeidet mer pondus.

\section{Lærdom 10: Klarspråk krever klarspråksledelse}

80 prosent av klarspråksarbeidet i SPK handlet om det operative forbedringsarbeidet, men det ville ikke vært mulig uten de 20 prosentene som handlet om ledelse. For SPK ble klarspråkledelse nøkkelen for å lykkes med klarspråk. 


\section{Summary}

The Norwegian Public Service Pension Fund (SPK) learned many lessons during its work on plain language from 2009 to 2012. One of them was that leadership was needed to overcome challenges and create results.

SPK improved more than 300 letters, changed all the content on the web and used plain language to explain the pension reform to our one million members and their 1,600 employers. SPK won the Plain Language Award in 2011.

The process was not easy. Leadership became the key to making plain language possible. In this article we share our experience and lessons learnt.

\section{Bibliografiske oplysninger}

Aanestad, Onar, 2016: Klarspråksledelse - mer enn gode tekster. I: Fra myndig maktspråk til klar kommunikasjon · Rapport fra Nordisk klarspråkskonferanse Oslo 28.-29. mai 2015, 7-18.

http://ojs.statsbiblioteket.dk/index.php/ksn

C Författarna och Nätverket för språknämnderna i Norden 